\title{
Quality Control of Certain Herbal Preparations Used for Respiratory Disorders in The Egyptian Market
}

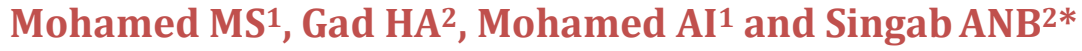 \\ ${ }^{1}$ Military Medical Academy, Ain Shams University, Egypt \\ ${ }^{2}$ Department of Pharmacognosy, Ain Shams University, Egypt
}

*Corresponding author: Professor Abdel Nasser B Singab, Department of Pharmacognosy, Faculty of Pharmacy, Ain Shams University, African Union

\section{Research Article \\ Volume 2 Issue 4}

Received Date: December 05, 2018

Published Date: December 21, 2018

DOI: $10.23880 /$ oajpr-16000168

Organization Street 11566 Cairo, Egypt, Tel: +2 022405 1120; Email: dean@pharma.asu.edu.eg

\section{Abstract}

Background: Herbal medicines comprise a crucial traditional remedy in the treatment of various respiratory ailments. However, the quality control of these herbal drugs is regarded as a main obstacle for their safety and efficacy.

Objectives: To assess the quality of different herbal preparations in the Egyptian market containing volatile oils used in the treatment of respiratory disorders.

Methods: Four different herbal preparations were purchased from the Egyptian pharmaceutical market: formula 1, 2 in form of powder and formula 3 and 4 inform of syrup. The essential oils of different herbal products were obtained by hydro-distillation, and subjected to GC/MS analysis for quantitative estimation. Furthermore, determination of pesticides residue, aflatoxins, certain microelements, heavy metals, and microbial contaminates were carried out.

Results: Fifty-four compounds were identified in formula 1, where anethole (34.15\%) was the main identified compound followed by p-cymene (8.16\%). In formula 2, estragole (10.81\%) and caryophyllene (8.65\%) followed by anethole (7.41\%) were the major identified compounds from $71.27 \%$ detected ones. Seven main components were identified in the oil of formula 3, the majors components were thymol (47.84\%) and anethole (34.73\%). Regarding formula 4, twenty four compounds were identified where thymol (63.24\%) and anethole (9.33\%) were the major constituents. Results of pesticide residues and heavy metals were in accordance with the international standards. All preparations were free from pathogenic organisms. No aflatoxins were detected.

Conclusion: The selected herbal preparations obey the official standards of health care.

Keywords: Herbal preparations; Quality control; Complex mixtures; Herbs; GC/MS

Abbreviations: HMPC: Herbal Medicinal Products; ACP: Agricultural Pesticide Committee; GC: Gas Chromatography; HP: Hewlett Packard; ECD: Electron Capture Detectors; LOQ: Limit of Quantitation.

\section{Introduction}

The use of plants, parts of plants and isolated phytochemicals for the prevention and treatment of 


\section{Open Access Journal of Pharmaceutical Research}

various health ailments has been in practice from time immemorial. It is estimated that about $25 \%$ of the drugs prescribed worldwide are derived from plants and 121 such active compounds are in use. Of the total 252 drugs in WHO's essential medicine list, $11 \%$ is exclusively of plant origin. Nearly $80 \%$ of African and Asian population depends on traditional medicines for their primary healthcare [1].

Quality control for the efficacy and safety of herbal products is essential. The quality criteria for herbal drugs are based on a clear scientific definition of the raw material. Depending on the type of preparation, sensory properties, physical constants, moisture, ash content, solvent residues, and adulterations have to be checked to prove identity and purity. Microbiological contamination and foreign materials, such as heavy metals, pesticide residues, aflatoxins, and radioactivity, also need to be tested to ensure purity and efficacy of herbal medicines. To prove the constant composition of herbal preparations, appropriate analytical methods have to be applied and different concepts have to be used in order to establish relevant criteria for uniformity [2].

Respiratory tract infections continue to be a major health challenge worldwide especially due to the increasingly fast development of resistance to the drugs currently in use. Respiratory diseases can be caused by several reasons, either by the presence of microorganisms or toxins in the environment (or in the saliva or mucus) which generally attack organisms with nutritional deficiencies, weak or immunologically predisposed to suffer any these discomforts. Among the most common are the respiratory flu, tonsillitis, bronchitis, pneumonia and influenza [3-6].

Essential oils have good reputations in the treatment of respiratory diseases in the traditional medicines. Because of the spread of multidrug resistant bacteria and the growing antibiotic resistance to them, many research groups have focused their research programmes on investigating the antimicrobial activities of plants and their extracts [7-9]. Essential oil of anise, bitter fennel fruit, eucalyptus, peppermint, tea and thyme are frequently used for the treatment of respiratory tract diseases. According to the Community herbal monographs of the Committee on Herbal Medicinal Products (HMPC), these oils can be applied generally based upon longstanding use $[9,10]$.

The present study attempts to assess the quality of different herbal preparations in the Egyptian market containing volatile oils used for the treatment of respiratory disorders to ensure their efficacy via quantitative analysis of main components and detection of different pharmacopeial constants to ensure their purity.

\section{Experimental}

\section{Herbal Preparations}

Herbal preparations used in this study were collected from different batches in the Egyptian market. The compositions of each herbal preparation are represented in Table 1.

\begin{tabular}{|c|c|c|}
\hline & \multicolumn{2}{|c|}{ Each 100 gm contains } \\
\hline \multirow{7}{*}{$\begin{array}{c}\text { Formula } 1 \text { (Powder) Batch no. } \\
\text { HS00679/14 HS0084/15 HS2007/15 }\end{array}$} & Salvia leaves & $10 \mathrm{gm}$ \\
\hline & Thyme leaves & $20 \mathrm{gm}$ \\
\hline & Anise fruit & $10 \mathrm{gm}$ \\
\hline & Guava leaves & $10 \mathrm{gm}$ \\
\hline & Mellisa leaves & $10 \mathrm{gm}$ \\
\hline & Fennel fruits & $20 \mathrm{gm}$ \\
\hline & Liquorice root & $20 \mathrm{gm}$ \\
\hline \multicolumn{3}{|c|}{ Each 100 gm contains } \\
\hline \multirow{8}{*}{$\begin{array}{c}\text { Formula } 2 \text { (Powder) } \\
\text { Batch no. } \\
\text { HS 0596/14 } \\
\text { HS 0636/14 HS0083/15 }\end{array}$} & Tillia leaves & $10 \mathrm{gm}$ \\
\hline & Guava leaves & $20 \mathrm{gm}$ \\
\hline & Pipermint leaves & $15 \mathrm{gm}$ \\
\hline & Verbascum flower & $5 \mathrm{gm}$ \\
\hline & Margoram leaves & $20 \mathrm{gm}$ \\
\hline & Fennel fruits & $10 \mathrm{gm}$ \\
\hline & Liquorice root & $10 \mathrm{gm}$ \\
\hline & \multicolumn{2}{|c|}{ Each $5 \mathrm{ml}$ contains } \\
\hline Formula 3 (Syrup) & Guava leaf extract & $41.70 \mathrm{mg}$ \\
\hline
\end{tabular}




\begin{tabular}{|c|c|c|}
\hline Batch no. & Thyme leaf extract & $83.33 \mathrm{mg}$ \\
\cline { 2 - 3 } $51471 / 15$ & Tilia flower extract & $83.33 \mathrm{mg}$ \\
\cline { 2 - 3 } $51171 / 15$ & Honey & $400 \mathrm{mg}$ \\
\cline { 2 - 3 } $51101 / 15$ & Fennel & $0.15 \mathrm{mg}$ \\
\cline { 2 - 3 } & Each 100 ml contain & $0.0666 \mathrm{gm}$ \\
\hline & Grindelia extract & $0.333 \mathrm{gm}$ \\
\hline \multirow{2}{*}{ Formula 4 (Syrup) } & Primula root extract & $0.399 \mathrm{gm}$ \\
\cline { 2 - 3 } Batch no. & Thyme extract & $0.0666 \mathrm{gm}$ \\
\cline { 2 - 3 } & Pimpinella root extract & $0.0088 \mathrm{gm}$ \\
\cline { 2 - 3 } & Anise oil & $0.2 \mathrm{gm}$ \\
\cline { 2 - 3 } & Flora rose extract & \\
\cline { 2 - 3 } \\
\cline { 2 - 3 }
\end{tabular}

Table 1: The compositions of each herbal preparation with their batch number.

\section{Authentic Reference Materials}

Pesticide standards: $\alpha-\mathrm{HCH}, \beta-\mathrm{HCH}, \delta-\mathrm{HCH}$, Heptachlor, Heptachlor-epoxide, Aldrin, $\gamma$-Chlordane, Dieldrin, p,p'DDE, Endrin, o,p'-DDT, p,p'-DDD and p,p'-DDT were purchased from Chem. Service, Inc (West chester, PA), supplied by Agricultural Pesticide Committee (APC), Ministry of Agriculture, Dokki, Giza, Egypt.

Aflatoxins: Aflatoxins $B_{1}, B_{2}, G_{1}$ and $G_{2}$ were supplied from Mycotoxins Central Lab. and Food Safety, National Research Center, Dokki, Giza, Egypt.

Heavy metals and microelements: Metals stock standards of $\mathrm{Cd}, \mathrm{Cu}, \mathrm{Fe}, \mathrm{Pb}$ and $\mathrm{Zn}$ were obtained from Merck, Darmstadt, Germany (Merck's ampoules; $1000 \mathrm{mg}$ ).

\section{Media for Microbiological Study}

Nutrient agar, MacConkey agar and Sabouraud dextrose. All of them are reconstituted and sterilized.

\section{Micro-organisms}

Bacterial strains: Bacillus cereus, B. polymexa, B. sphaericus, B. subtilis, Micrococcus spp. and Staphylococcus epidermidis. Fungi: Aspergillus candidus, A. niger, A. versicolor, Fusarium equiseti, F. oxysporum, Mucor pusillus and Penicillum spp were all supplied by Agricultural Pesticide Committee (APC), Ministry of Agriculture, Dokki, Giza, Egypt for microbial count measurements.

\section{Sample Preparation and Instrumentation}

Determination of pesticide residues: Plant extract prepared by immersion of $2 \mathrm{~g}$ of the dry samples in $100 \mathrm{ml}$ of recently boiled distilled water for 5 minutes. Each sample was analyzed by Gas chromatography (GC)
Hewlett Packard (HP) serial 6890, Ramsey, Minnesota, USA. Gas Chromatography equipped with different detectors, i.e. electron capture (ECD). Analysis of the pesticides was performed on two capillary columns, HP-5 (5\%-phenylmethylpolysiloxane) and DB-35 (35\%phenylmethylpolysiloxane). Nitrogen was used as a carrier gas at a flow rate of $1 \mathrm{ml} / \mathrm{min}$. The temperatures of injector and interface were $250^{\circ} \mathrm{C}$ and $300^{\circ} \mathrm{C}$, respectively. The temperature program for GC was as follow; initial temperature was $100^{\circ} \mathrm{C}$ for $1 \mathrm{~min}$, raised at rate of $25^{\circ} \mathrm{C} / \mathrm{min}$ to $170^{\circ} \mathrm{C}$, isothermal for $1 \mathrm{~min}$, raised at a rate of $3^{\circ} \mathrm{C}$ to $230^{\circ} \mathrm{C}$, then isothermal for $1 \mathrm{~min}$, finally raised at a rate of $8^{\circ} \mathrm{C}$, then isothermal for $5 \mathrm{~min}$. The Codex quality assurance criteria were followed to determine the performance of the multi-residue method. Recoveries and limit of quantitation (LOQ) were determined on samples at spiking levels. The average recoveries ranged between $81 \%$ and $104 \%$ and quantitation limits between 0.003 and $0.043 \mathrm{mg} / \mathrm{kg}[11,12]$.

Determination of certain microelements and heavy metals: Samples have different batch numbers of Formula 1 and 2 are collected from different pharmacies for analysis of heavy metals, using atomic absorption spectrophotometric method $[12,13]$. Using wet digestion method, $1.5 \mathrm{~g}$ of each powdered sample were digested in Kjeldahl flasks set at $100{ }^{\circ} \mathrm{C}$ till complete digestion then diluted by deionized water and transferred quantitatively to $50 \mathrm{ml}$ volumetric flask. Filtrate was analyzed by Thermo Elemental model: Solar $M$ Atomic Absorption Spectrophotometer was used for all the measurements, the current; wavelength and slit bandwidth of each element was adjusted automatically by the instrument software.

Determination of microbial contaminants: Eighteen samples from different batches of herbal preparations 


\section{Open Access Journal of Pharmaceutical Research}

(Formula 1 and 2) were examined for determination of microbial contaminants using viable count method.

\section{Viable count method}

One $g$ of each of the herbal preparations was mixed separately, with $9 \mathrm{ml}$ sterile peptone water and then 10 fold serial dilutions were made. Five level-spacing 1 logarithmic unit were investigated by pipetting $1 \mathrm{ml}$ from each level in a plate, $15 \mathrm{ml}$ of nutrient agar (agar for bacterial count, Sabouraud dextrose agar for fungal count and MacConkey agar for pathogenic coliform count), were added. The contents were allowed to solidify and inverted plates were incubated at $37^{\circ} \mathrm{C}$, examined after 2 days for both bacterial and coliform count, while for fungal count the plates were incubated at $28^{\circ} \mathrm{C}$, examined after 7 days. Suitable dilutions were counted [14].

Determination of aflatoxins: Determination of aflatoxins was carried out on herbal preparations (Formula 1 and 2) by blending 25g sample with $5 \mathrm{~g}$ sodium chloride and $100 \mathrm{~mL}$ methanol: water $(80: 20)$ using a high-speed blender jar for one minute, then filtered through fluted filter paper. $10 \mathrm{~mL}$ of the filtrate were diluted with $40 \mathrm{~mL} d$ water, and then filtered through a glass microfiber glass syringe barrel. Pass $8 \mathrm{ml}$. and subjected to HPLC analysis. Waters Binary Pump Model 1525, a Model Waters 1500 Rheodyne manual injector, a Waters 2475 Multi-Wavelength Fluorescence Detector, and a data workstation with software Breeze 2 (USA). Filtered diluted to extract (0.8gm sample equivalent) completely through an Afla Test $囚-P$ affinity column at a rate of 1-2 drops/second. Pass $10 \mathrm{ml} \mathrm{d}$ water through the column at a rate of 2 drops/second, elute the affinity column by passing one mL HPLC grade methanol through the column at a rate of 1-2 drops/second, collected in a glass vial, evaporated until dryness under a stream of nitrogen (immuno-affinity chromatography) [15].

Sample was derivatized using $100 \mu \mathrm{L}$ of trifluoracetic acid (TFA), left for $15 \mathrm{~min} .900 \mu \mathrm{L}$ of water: acetonitrile (9:1 v/v) were added and mixed well by vortex for $30 \mathrm{~s}$, then the mixture was used for HPLC analysis using reversed phase column [Phenomenex C18 ( $250 \times 4.6 \mathrm{~mm}$ i.d.), $5 \mu \mathrm{m}$ from water corporation (USA)]. An isocratic system with water: methanol: acetonitrile (6:3:1). The separation was performed at an ambient temperature at a flow rate of $1.0 \mathrm{~mL} / \mathrm{min}$. The injection volume was $20 \mu \mathrm{L}$ for both standard solutions and sample extracts. The fluorescence detector was operated at wavelength of $360 \mathrm{~nm}$ for excision and 440 $\mathrm{nm}$ for emission [15].
GC/MS for analysis of volatile oils of herbal preparations: The essential oils were separately prepared by hydro distillation of $100 \mathrm{gm}$ of dried powder from herbal preparations (Formula 1 and 2) and $400 \mathrm{ml}$ of each syrup (Formula 3 and 4) separately for four hours. The distillate in each was dried over anhydrous sodium sulphate and kept in the refrigerator until analysis. GC/MS analysis of the essential oil was carried out on Shimadzu Model GC-17A gas chromatograph interfaced with a Shimadzu model QP-5000 mass spectrometric detector. The instrument was controlled by the Shimadzu Class-5000 Version 2.2 software containing a NIST62 (National Institute of Standards and Technology) MS library. Volatiles were separated on a DB5-MS column (30 $\mathrm{m}$ length, $0.25 \mathrm{~mm}$ inner diameter, and $0.25 \mu \mathrm{m}$ film thickness J\&W Scientific, Santa Clara, Calif.). Injections were made in the split mode (54:1), the gas chromatograph was operated under the following conditions: injector $240^{\circ} \mathrm{C}$ column oven $40^{\circ} \mathrm{C}$ for $3 \mathrm{~min}$, then programmed at a rate of $12^{\circ} \mathrm{C} / \mathrm{min}$ to $180{ }^{\circ} \mathrm{C}$, kept at $180{ }^{\circ} \mathrm{C}$ for $5 \mathrm{~min}$, and finally ramped at a rate of 40 ${ }^{\circ} \mathrm{C} / \mathrm{min}$ to $240^{\circ} \mathrm{C}$ and kept for $5 \mathrm{~min}$. Helium carrier gas, flow rate was $0.9 \mathrm{~mL} / \mathrm{min}$. The transfer line and ionsource temperatures were adjusted at 230 and $180{ }^{\circ} \mathrm{C}$, respectively. The HP quadrupole mass spectrometer was operated in the electron ionization mode at $70 \mathrm{eV}$. The scan range was set at $40-500 \mathrm{~m} / \mathrm{z}$. Peaks were first deconvoluted using AMDIS software (www.amdis.net) and identified by its retention indices (RI) relative to $\mathrm{n}$ alkanes (C6-C20), mass spectrum matching to NIST library database and with authentic standards when available. The volatile components were identified by comparing their relative retention times and mass fragmentation patterns with those of the database libraries (Wiley7n.1 and wiley 7 NIST05 database) as well as the published data. The percentage of each component was determined by computerized peak area measurements. A series of authentic $n$-alkanes was subjected to GC under the same conditions, the retention time of each $n$-alkane was observed and Kovats index of each constituent of the oil was calculated by using special computer program. Norway).

\section{Results and Discussion}

\section{Detection of Pesticide Residues}

Persistent organic pollutants (POPs) include organic chemicals, such as the synthetic aromatic chlorinated hydrocarbons, which are only slightly soluble in water and are persistent or stable in the presence of sunlight, moisture, air and heat. In the past, they were extensively used in agriculture as pesticides. Thirteen pesticides were 
studied for identification and quantification. The detected residues organochlorine pesticides included: alpha- $\mathrm{HCH}$, beta- $\mathrm{HCH}$, delta- $\mathrm{HCH}$, heptachlor, heptachlor-epoxide, aldrin, Gama chlordane, dieldrin, $p, p$-DDE, endrin, o.pDDT, $p, p-D D D$ and $p, p-D D T$.

By analysis of GC chromatogram (Figures 1a \& 1b), it was found that Heptachlor, Dieldrin and p.p-DDT were present in (Formula 1) in concentration of 0.0025, 0.001 and $0.0002 \mathrm{mg} / \mathrm{kg}$ respectively. However, (Formula 2) contained only Heptachlor and p.p-DDT in concentration of 0.003 and $0.002 \mathrm{mg} / \mathrm{kg}$. These results are incompliance with the international standards limit as the concentration of Heptachlor, Dieldrin and p.p-DDT should not exceed $0.05,0.05$ and 0.2 respectively $[12,16,17]$.

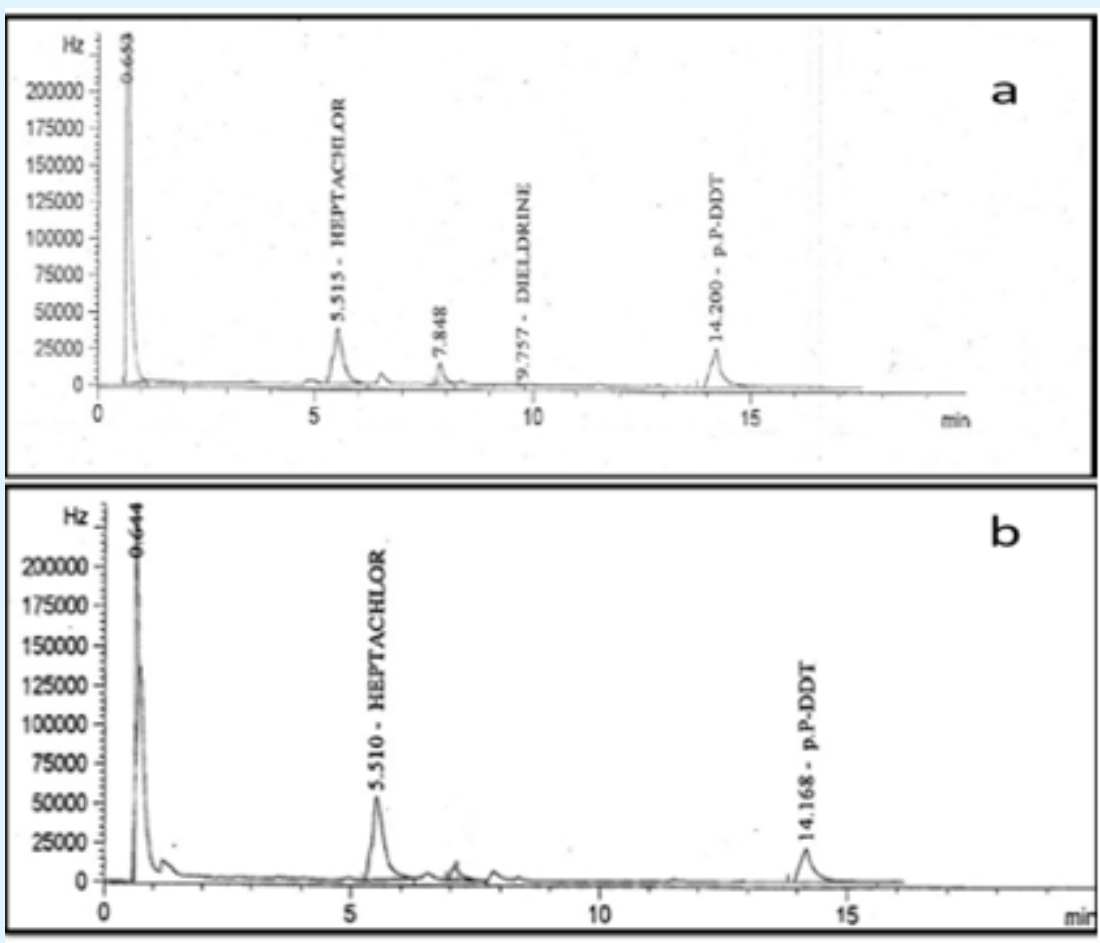

Figure 1: GC chromatogram for pesticide residue in (a): Formula 1, (b) Formula 2.

\section{Determination of Certain Microelements and Heavy Metals}

Contamination of herbal materials with toxic substances can be attributed to many causes. These include environmental pollution (i.e. contaminated emissions from factories and leaded petrol and contaminated water, including runoff water, which finds its way into rivers, lakes and the sea, and some pesticides), soil composition and fertilizers. This contamination of the herbal material leads to contamination of the products during various stages of the manufacturing process [16,17].

Samples have different batch numbers of Formula 1 and 2 are collected from different pharmacies for analysis of heavy metals. Results are tabulated in Table 2. It was found that all preparations contained Copper and Zinc. However, Cadmium and Lead are absent. Comparing the daily intake dose with the acceptable daily levels, it was concluded that the levels of Copper and Zinc did not exceed the maximum acceptable limits [18].

\begin{tabular}{|c|c|c|c|c|c|}
\hline \multirow{2}{*}{ Samples } & \multicolumn{5}{|c|}{ Heavy metals } \\
\cline { 2 - 6 } & Pb & Cd & Cu & Zn & Fe \\
\hline Formula 1 & Nd & Nd & 6.27 & 7.82 & 19.72 \\
\hline Formula 2 & $\mathrm{Nd}$ & $\mathrm{Nd}$ & 7.32 & 8.12 & 20.43 \\
\hline MPL $^{*}$ (mg/kg) & 10 & 0 & 20 & 50 & $* *$ \\
\hline
\end{tabular}

Table 2: Concentrations of certain microelements and heavy metals of (Formula 1 and 2) (mg/kg). ${ }^{*}$ Maximum permissible limits (MPL) ** (Withdrawn by WHO), Nd; not determined. 


\section{Open Access Journal of Pharmaceutical Research}

\section{Determination of Microbial Contaminants}

The need for the microbial quality control of commercial herbs is well clarified and recognized. This study aimed to evaluate the commercial herbs, as for their microbial contents. In addition, this study reflected the urgent need to reassess our methods of controlling the microbial contamination of commercial herbs. Total counts were used to assess sanitary quality, organoleptic acceptability, safety and utility of various herbal products. High viable count indicates poor sanitary quality, while low total counts do not necessarily carry the opposite implication [19].

Nine samples from three different batches of Formula 1 and 2 under study were represented by (A1, A2, A3, B1, B2, B3, C1, C2 and C3) and (A1o, A2o, A3o, B1o, B2o, B3o,
C1o, C2 o and C3 o) respectively. The results obtained for bacterial and fungal count of both commercial samples were presented in Table 3.

The microbiological examination included the determination of total aerobic bacterial, total fungal and coliform counts as well as qualitative tests for identification of bacteria and fungi. Regarding Formula1 samples, it was found that the bacterial count ranged from $0-1 \times 10^{3} \mathrm{cfu} / \mathrm{gm}$. Three samples out of nine were free from bacteria while fungal count ranged from $0-2 \times 10^{2}$ $\mathrm{cfu} / \mathrm{gm}$ and six samples were free from fungi. Qualitative tests for bacteria showed that three samples had $S$. epidemidis, while the main fungal isolates were $M$ pusillus, F. oxysporum and $A$. candidus along with presence of yeast.

\begin{tabular}{|c|c|c|c|c|c|c|c|}
\hline & & \multicolumn{3}{|c|}{ Bacterial content } & \multicolumn{3}{|c|}{ Fungal content } \\
\hline $\begin{array}{c}\text { Batch } \\
\text { No. }\end{array}$ & $\begin{array}{c}\text { Serial } \\
\text { No. }\end{array}$ & $\begin{array}{c}\text { Total count } \\
\text { cfu/gm }\end{array}$ & $\begin{array}{c}\text { Coliform count } \\
\text { cfu/gm }\end{array}$ & $\begin{array}{c}\text { Detected Bacterial } \\
\text { species }\end{array}$ & $\begin{array}{c}\text { Total count } \\
\text { cfu/gm }\end{array}$ & Moulds & Yeas \\
\hline \multirow{3}{*}{$\mathbf{A}$} & 1 & $1.0 \times 10$ & 0 & B. polymexa & 0 & - & - \\
\hline & 2 & $1.0 \times 10$ & 0 & Micrococc-us spp. & $1.0 \mathrm{X} 10$ & M. pusillus & - \\
\hline & 3 & $1.0 \times 10$ & 0 & Micrococc-us spp. & 0 & - & - \\
\hline \multirow{3}{*}{ B } & 1 & $2.0 \times 10$ & 0 & B. subtilis & 0 & - & - \\
\hline & 2 & 0 & 0 & - & $1.0 \times 10^{2}$ & $\begin{array}{c}F . \\
\text { Oxysporum }\end{array}$ & - \\
\hline & 3 & 0 & 0 & - & 0 & - & - \\
\hline \multirow{3}{*}{ C } & 1 & $1.0 \times 10^{3}$ & 0 & S. epidermidis & 0 & - & - \\
\hline & 2 & 0 & 0 & - & $2.0 \times 10^{2}$ & A. candidus & + \\
\hline & 3 & $3.0 \times 10$ & 0 & B. subtilis & 0 & - & - \\
\hline \multirow{3}{*}{$\mathrm{A}^{\mathrm{o}}$} & 1 & $2.0 \times 10$ & 0 & B. subtilis & 0 & - & - \\
\hline & 2 & $2.0 \times 10$ & 0 & B. subtilis & $1.0 \times 10$ & A. niger & - \\
\hline & 3 & $4.0 \times 10$ & 0 & S. epidermidis & 0 & - & - \\
\hline \multirow{3}{*}{$\mathrm{B}^{o}$} & 1 & $1.0 \times 10$ & 0 & B. sphaericus & 0 & - & - \\
\hline & 2 & $1.0 \times 10$ & 0 & S. epidermidis & 0 & - & - \\
\hline & 3 & $1.0 \times 10$ & 0 & B. subtilis & 0 & - & - \\
\hline \multirow{3}{*}{$\mathrm{C}^{\mathrm{o}}$} & 1 & $1.0 \times 10^{2}$ & 0 & B. subtilis & $1.0 \times 10$ & A.versicolor & - \\
\hline & 2 & $1.0 \times 10$ & 0 & S.epidermidis & 0 & - & - \\
\hline & 3 & $3.0 \times 10$ & 0 & B. cereus & $1.0 \times 10^{3}$ & F. equiseti & + \\
\hline
\end{tabular}

Table 3: Microbial contents of different batches of Formula 1 and 2.

A., Aspergillus; B., Bacillus; F, Fusarium; S., Staphylococcus

However, samples of Formula 2 showed that the bacterial count ranged from $10-1 \times 10^{2} \mathrm{cfu} / \mathrm{gm}$. All samples were contaminated with bacteria contaminants. Regarding fungi, moulds were found in three samples out of nine, while yeast was present in one sample. Qualitative tests for bacteria showed that Bacillus species were identified from 6 samples while $S$. epidermidis was identified from three samples of commercial herbal flu regarding the fungal contents, the main isolates were $A$. niger, $A$. versicolor and $F$. equiseti.

From the present study, it was generally recommended that both herbal preparations (Formula 1 and 2) were slightly contaminated with fungi and bacteria. All herbal preparations contain no pathogenic organisms [19]. 


\section{Open Access Journal of Pharmaceutical Research}

\section{Determination of Aflatoxins}

Aflatoxins are a naturally occurring toxic metabolite produced by certain fungi (Aspergillus flavis and $A$. Parasiticus) However, A. flavis is common and widespread. These mycotoxins could produce hepatocarcinoma as a result of aflatoxicosis when given in very low doses for laboratory animals. Consequently, the exposure of humans of these aflatoxins has dangerous adverse reactions [20]. Conditions like increasing moisture content; high temperature and insect damage of natural products are major factors for mould infestation and toxin production.

Tests for aflatoxins are designed to detect the possible presence of aflatoxins B1, B2, G1 and G2, which are highly toxic contaminants in any material of plant origin. HPLC chromatograms of aflatoxins in Formula 1 and 2 were presented in Figures 2a and 2b. It was concluded that the total concentration of aflatoxins in herbal preparations (Formula 1 and 2) is $(0.52 \mu \mathrm{g} / \mathrm{kg})$ and $(1.63 \mu \mathrm{g} / \mathrm{kg})$ respectively which is much lower than the acceptable limits.

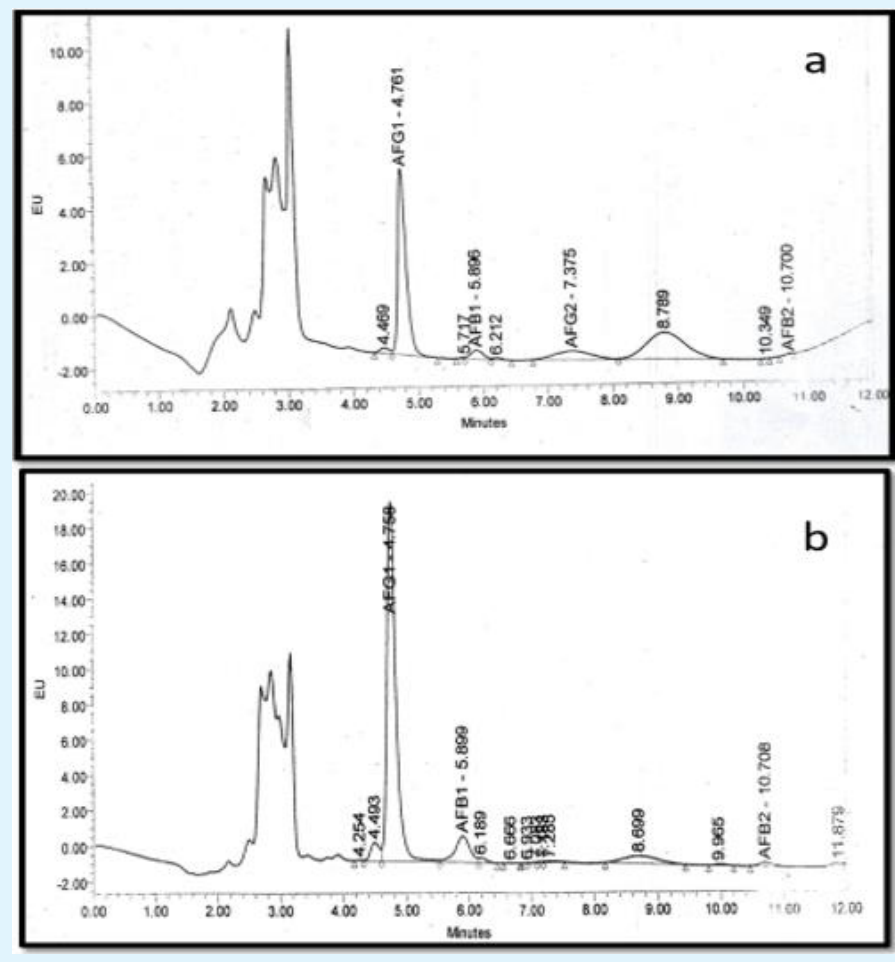

Figure 2: HPLC chromatograms of aflatoxins in (a) Formula 1, (b) Formula 2.

\section{GC/MS Analysis of Essential Oils of Different Herbal Preparations}

Essential oils of four herbal preparations (Formula 1, 2, 3 and 4) were subjected to GC/MS analysis. Physical characters, yield \%, total number of identified compounds and $\%$ of identified compounds in each herbal preparation was presented in Table 4 (Figure 3).

\begin{tabular}{|c|c|c|c|c|}
\hline Sample & Color of oil & Yield \% & Total no. of identified compounds & \% of identified compounds \\
\hline Formula 1 & Pale yellow & 2.4 & 54 & 78.34 \\
\hline Formula 2 & Pale yellow & 2.1 & 43 & 77.13 \\
\hline Formula 3 & Dark yellow & 1.8 & 24 & 81.9 \\
\hline Formula 4 & Straw yellow & 1.6 & 8 & 97.34 \\
\hline
\end{tabular}

Table 4: Physical characters, yield \%, total number of identified compounds and \% of identified compounds of herbal preparations. 


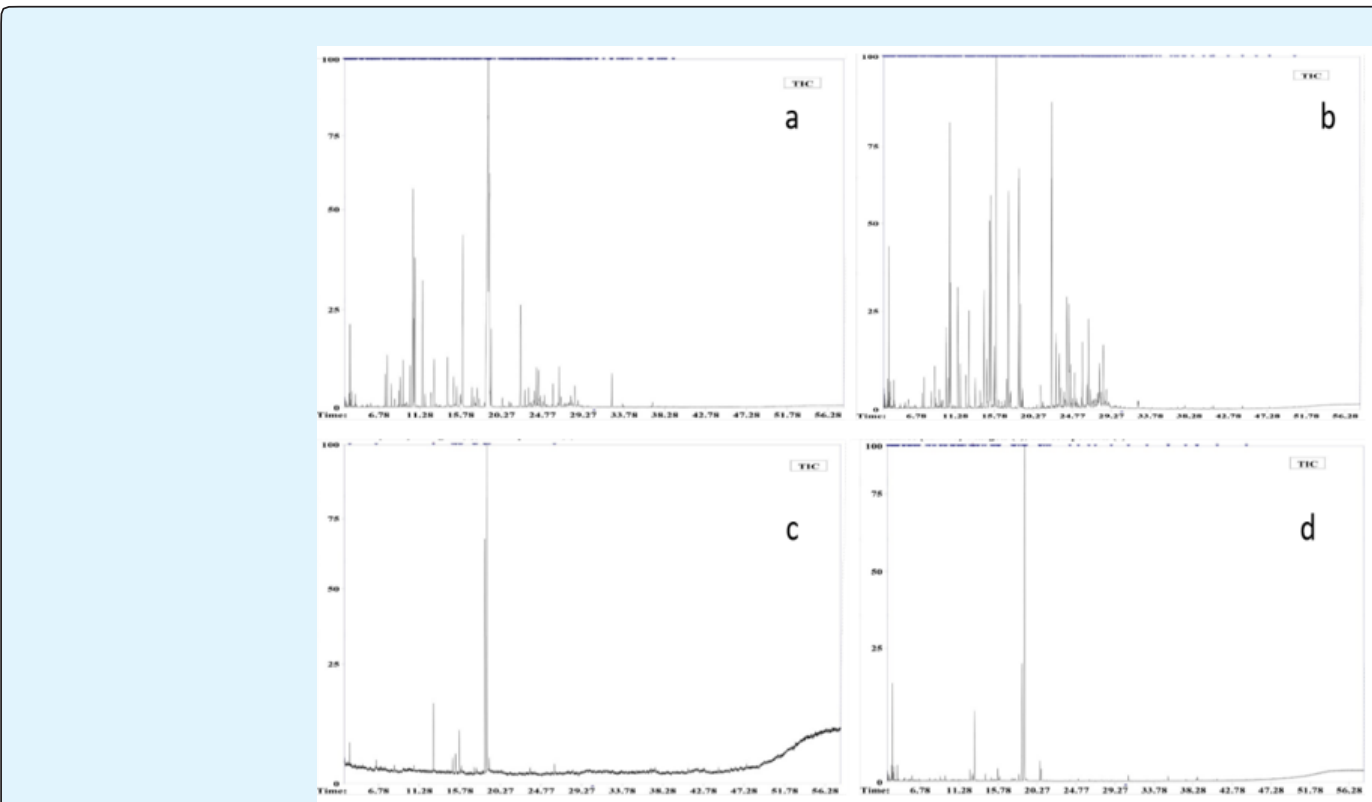

Figure 3: GC/MS chromatograms of essential oil of (a) Formula 1, (b) Formula 2, (c) Formula 3, (d) Formula 4.

Fifty-four compounds and forty-three representing $(78.34 \% \& 77.13 \%)$ of the total detected compounds were identified in Formula 1 and 2 respectively. Anethole $(34.15 \%)$ was the main identified compound followed by p-cymene $(8.16 \%)$ and estragole $(6.96 \%)$ in Formula 1 with monoterpenes and oxygenated monoterpenes representing $(15.58 \%)$ and $(54.11 \%)$ respectively. However, sesquiterpenes and oxygenated sesquiterpenes representing (6.06\%) and $(0.32 \%)$ respectively. Regarding Formula 2, estragole (10.81\%) and caryophyllene $(8.65 \%)$ followed by anethole $(7.41 \%)$ were the major detected constituents. Monoterpenes and oxygenated monoterpenes representing $(8.95 \%)$ and $(37.69 \%)$ respectively in addition to sesquiterpenes and oxygenated sesquiterpenes representing (18 .56\%) and (5.16\%) respectively.
Concerning Formula 3, seven main components were identified representing (97.34\%) of the total detected compounds, the major components were thymol $(47.84 \%)$ and anethole (34.73\%) followed by linalool (6.25\%) and $\alpha$-terpineol (4.38\%). All the compounds representing oxygenated monoterpenes. Twenty-four compounds were identified representing (81.9\%) of the total detected compounds in formula 4. Thymol (63.24\%) was the major component followed by anethole (9.33\%) with monoterpenes and oxygenated monoterpenes representing $(0.12 \%)$ and $(78.76 \%)$ respectively. Identified components in the essential oil of each herbal preparation with their Kovat index and relative abundance are presented in Table 5.

\begin{tabular}{|c|c|c|c|c|c|c|}
\hline \multirow{2}{*}{ Identified Compounds } & \multicolumn{3}{|c|}{ Kovat's index (RI) } & \multicolumn{4}{c|}{ Rel. abundance* (\%) } \\
\cline { 2 - 7 } & Cal. & Reported & Formula 1 & Formula 2 & Formula 3 & Formula 4 \\
\hline Furfural & 828 & 831 & -- & -- & -- & 0.17 \\
\hline Chromor & 860 & 861.7 & 0.07 & -- & -- & 0.33 \\
\hline Xylol & 843 & 850 & 0.01 & 0.14 & -- & -- \\
\hline Camphene & 941 & 946 & 0.35 & -- & -- & -- \\
\hline Almond oil & 947 & 956 & 0.13 & 0.25 & -- & -- \\
\hline Sabinen & 968 & 971 & -- & 0.59 & -- & -- \\
\hline Morillol & 977 & 982 & 0.51 & 0.09 & -- & 0.34 \\
\hline Myrcene & 988 & 990 & 0.72 & -- & -- & -- \\
\hline Fellandrene & 1003 & 1005 & 0.08 & 0.13 & -- & -- \\
\hline Carene & 1009 & 1009 & 0.03 & -- & -- & -- \\
\hline
\end{tabular}


Open Access Journal of Pharmaceutical Research

\begin{tabular}{|c|c|c|c|c|c|c|}
\hline Terpilene & 1015 & 1019 & 0.7 & -- & -- & -- \\
\hline p-cymene & 1024 & 1025 & 8.16 & -- & -- & -- \\
\hline Carvene & 1028 & 1035 & 2.08 & 6.01 & -- & -- \\
\hline Menthone & 1129 & 1129 & -- & 1.04 & -- & -- \\
\hline Cineole & 1030 & 1030 & -- & 1.8 & -- & -- \\
\hline Eucalyptol & 1031 & 1031 & 3.21 & -- & -- & -- \\
\hline Ocimene & 1046 & 1046 & 0.03 & -- & -- & -- \\
\hline Hyacinthin & 1045 & 1045 & 0.02 & 0.04 & -- & -- \\
\hline Moselene & 1060 & 1062 & -- & 1.95 & -- & -- \\
\hline$\alpha$-pinene & 1060 & 1063 & 3.38 & 0.27 & -- & -- \\
\hline Continental oil & 1071 & 1071.6 & -- & -- & -- & 0.07 \\
\hline Fenchone & 1089 & 1089 & 0.32 & -- & -- & 0.86 \\
\hline Linalool & 1100 & 1100 & 0.97 & -- & 6.25 & 0.52 \\
\hline Chrysanthone & 1107 & 1124 & 0.07 & -- & -- & -- \\
\hline Cymol & 1111 & 1113 & -- & 0.48 & -- & 0.11 \\
\hline Thyjon & 1117 & 1117 & 0.03 & -- & 1.6 & -- \\
\hline Bornanone & 1140 & 1143 & 1.18 & -- & -- & 0.59 \\
\hline Estragol & 1158 & 1158 & 6.96 & 10.81 & -- & 0.15 \\
\hline Menthol & 1175 & 1174 & -- & 5.08 & -- & -- \\
\hline Pinanone & 1176 & 1176 & 0.04 & -- & -- & -- \\
\hline Borneol & 1178 & 1178 & 1.77 & -- & -- & 0.25 \\
\hline Camphor & 1168 & 1168 & 0.08 & 0.1 & 1.46 & 0.2 \\
\hline Terpineol & 1179 & 1179 & 0.48 & 4.92 & 4.38 & 1.1 \\
\hline Cymene & 1186 & 1186 & 0.05 & -- & -- & 0.12 \\
\hline$\alpha$-Terpinoel & 1194 & 1193 & -- & 1.16 & -- & -- \\
\hline Carveol & 1230 & 1229 & -- & 0.2 & -- & -- \\
\hline Neral & 1240 & 1240 & 0.11 & -- & -- & -- \\
\hline Cartegine & 1252 & 1252 & 0.22 & -- & -- & -- \\
\hline Carvone & 1256 & 1256 & 0.59 & -- & -- & 0.2 \\
\hline Bergamol & 1257 & 1256 & -- & 5.81 & -- & -- \\
\hline Pipretone & 1258 & 1258 & 0.03 & 0.27 & -- & 0.39 \\
\hline Agallaiene & 1280 & 1292 & -- & 0.39 & -- & -- \\
\hline Citeral & 1286 & 1197 & 0.13 & -- & -- & -- \\
\hline Anethole & 1298 & 1199 & 34.15 & 7.41 & 34.73 & 9.33 \\
\hline cymenol & 1307 & 1299 & -- & -- & 1.08 & -- \\
\hline Thymol & 1310 & 1297.6 & 1.42 & 2.21 & 47.84 & 63.24 \\
\hline Eugenol & 1336 & 1335 & -- & -- & -- & 1.67 \\
\hline Carvacrol & 1358 & 1297.6 & 3.11 & 0.34 & -- & 0.15 \\
\hline Prunolide & 1366 & 1365 & -- & -- & -- & 0.97 \\
\hline Ylangene & 1376 & 1370.9 & 0.02 & -- & -- & -- \\
\hline Copaene & 1380 & 1392 & 0.1 & -- & -- & -- \\
\hline Lutein & 1407 & 1407 & 0.01 & -- & -- & -- \\
\hline Virdiflorene & 1419 & 1492 & 0.02 & -- & -- & -- \\
\hline Caryophyllene & 1426 & 1440 & 3.15 & 8.65 & -- & -- \\
\hline Calrene & 1435 & 1427.7 & 0.02 & 0.05 & -- & -- \\
\hline Alloaromadendrene & 1440 & 1415 & -- & 1.53 & -- & -- \\
\hline Humulene & 1461 & 1459 & 0.36 & 0.96 & -- & -- \\
\hline Guaiene & 1480 & 1423 & -- & 0.04 & -- & -- \\
\hline Muurolenne & 1483 & 1486 & 0.18 & 2.53 & -- & -- \\
\hline Curcumene & 1487 & 1474 & -- & 0.19 & -- & -- \\
\hline
\end{tabular}


Open Access Journal of Pharmaceutical Research

\begin{tabular}{|c|c|c|c|c|c|c|}
\hline Eudesmene & 1495 & 1483 & 0.87 & -- & -- & -- \\
\hline Selinene & 1504 & 1491.6 & 0.82 & 2.39 & -- & -- \\
\hline Longipinene & 1509 & 1353 & 0.02 & -- & -- & -- \\
\hline Bisabolene & 1500 & 1501.2 & 0.23 & 0.75 & -- & -- \\
\hline Cadinine & 1522 & 1563 & 0.12 & 0.21 & -- & -- \\
\hline Calamenene & 1530 & 1516 & -- & 0.93 & -- & -- \\
\hline Patchoulene & 1536 & 1464 & 0.03 & -- & -- & -- \\
\hline Globulol & 1569 & 1568 & -- & 1.5 & -- & -- \\
\hline Persicol & 1579 & 1578 & -- & -- & -- & 0.09 \\
\hline Viridiflorol & 1601 & 1594 & 0.23 & 2.17 & -- & -- \\
\hline Ledol & 1613 & 1568 & -- & 0.18 & -- & -- \\
\hline Globulol & 1623 & 1642 & -- & 0.24 & -- & -- \\
\hline Guaiene & 1637 & 1423 & 0.12 & 0.33 & -- & -- \\
\hline Cadinol & 1655 & 1646 & 0.09 & -- & -- & -- \\
\hline Torreyol & 1656 & 1646 & -- & 1.07 & -- & -- \\
\hline Camphor-juniper & 1667 & 1675 & 0.64 & 1.87 & -- & -- \\
\hline Ascarboil & 1773 & 1693 & -- & -- & -- & 0.51 \\
\hline Ethyl palmatate & 1990 & 1991 & -- & -- & -- & 0.36 \\
\hline Epimanool & 2063 & 1970 & 0.11 & -- & -- & -- \\
\hline Staric acid & 2135 & 2133 & 0.01 & 0.05 & -- & -- \\
\hline Mandenol & 2168 & 2155 & -- & -- & -- & 0.18 \\
\hline Total identified & & & $\mathbf{7 8 . 3 4}$ & $\mathbf{7 7 . 1 3}$ & $\mathbf{9 7 . 3 4}$ & $\mathbf{8 1 . 9}$ \\
\hline
\end{tabular}

Table 5: Identified components in the essential oils of each herbal preparation with their Kovat's index and relative abundance.

\section{Conclusion}

This study was done to check the quality, safety of certain herbal formulations in the Egyptian market. The results assured that these herbal products are effective and safe when compared to the international standards. This study recommends to screen and investigate other products for safety and efficacy.

\section{References}

1. Sahoo N, Manchikanti P, Dey S (2010) Herbal drugs: Standards and regulation. Fitoterapia 81(6): 462-471.

2. Bookout W, Khachatoorian LB (2007) Regulation and Quality Control in Veterinary Herbal Medicine. Mosby: Saint Louis pp: 99-119.

3. Coon JT, Ernst E (2004) Andrographis paniculata in the treatment of upper respiratory tract infections: a systematic review of safety and efficacy. Planta Med 70(4): 293-298.

4. Cruz-Vega DE, Verde-Star MJ, Salinas-Gonzalez N, Rosales-Hernandez B, Estrada-Garcia I, et al. (2008) Antimycobacterial activity of Juglans regia, Juglans mollis, Carya illinoensis and Bocconia frutescens. Phytother Res 22(4): 557-559.
5. Deharo E, Baelmans R, Gimenez A, Quenevo C, Bourdy G (2004) In vitro immunomodulatory activity of plants used by the Tacana ethnic group in Bolivia. Phytomedicine 11(6): 516-522.

6. Heitzman ME, Neto CC, Winiarz E, Vaisberg AJ, Hammond GB (2005) Ethnobotany, phytochemistry and pharmacology of Uncaria (Rubiaceae). Phytochemistry 66(1): 5-29.

7. Nilani P, Duraisamy B, Dhamodaran P, Ravichandran S, Elango K (2010) Effect of selected antiasthmatic plant constituents against micro organism causing upper respiratory tract infection. Anc Sci Life 29(3): 30-32.

8. Hedayat KM (2008) Essential Oil Diffusion for the Treatment of Persistent Oxygen Dependence in a Three-Year-Old Child With Restrictive Lung Disease With Respiratory Syncytial Virus Pneumonia. Explore: Explore 4(4): 264-266.

9. Horváth G, Ács K (2015) Essential oils in the treatment of respiratory tract diseases highlighting their role in bacterial infections and their antiinflammatory action: a review. Flavour Frag J 30(5): 331-341.

10. Fabio A, Cermelli C, Fabio G, Nicoletti P, Quaglio P (2007) Screening of the antibacterial effects of a 


\section{Open Access Journal of Pharmaceutical Research}

variety of essential oils on microorganisms responsible for respiratory infections. Phytother Res 21(4): 374-377.

11. Halabi SF, (2015) The Codex Alimentarius Commission, Corporate Influence, and International Trade: A Perspective on FDA's Global Role. Am J Law Med 41(2-3): 406-421.

12. Cwiek-Ludwicka K, Wojciechowska-Mazurek M, Brulinska-ostrowska E, Starska K, (1997) Activity of the Codex Alimentarius Commission FAO/WHO on quality assurance in the laboratory. Rocz Panstw Zakl Hig 48(4): 371-379.

13. Yamada Y (2002) International food standards (2). Codex Alimentarius Commission and food safety. Food Hyg Safe Sci 43(4): 249-252.

14. Baker BM (1980) Expiration dates, sterile or unsterile? That is the question. Hosp Top 58(6): 34-35.

15. Weaver CM, Trucksess MW (2010) Determination of aflatoxins in botanical roots by a modification of
AOAC Official Method 991.31: single-laboratory validation. J AOAC Int 93(1): 184-189.

16. WHO (2000) General Guidelines for Methodologies on Research and Evaluation of Traditional Medicines. World Health Organization pp: 1-80.

17. WHO (2007) Monographs on selected medicinal plants. World Health Organization 3: 1-390

18. Karak $\mathrm{T}$ and Bhagat RM, (2010) Trace elements in tea leaves, made tea and tea infusion: A review. Food Res Int 43(9): 2234-2252.

19. Gad GFM, Abdel-Hamid AM, Farag ZSH (2014) Antibiotic resistance in lactic acid bacteria isolated from some pharmaceutical and dairy products. Braz J Microbiol 45(1): 25-33.

20. Farag RS, Daw ZY, Abo-Raya SH (1989) Infuence of some spice essential oils on Aspergillus parasiticus growth and production of aflatoxins in a synthetic medium. J Food Prot 54(1): 74-76. 